\title{
ENVIRONMENTAL CROWDSOURCING IN MOSCOW: UNDERRATED OPPORTUNITIES
}

\author{
Maria Savoskul \\ Department of economic and social geography of Russia \\ Lomonosov Moscow State University \\ GSP-1 Leninskie gory, Moscow, Russian Federation, 119991 \\ savoskul@yandex.ru \\ Viktoria Bityukova \\ Department of economic and social geography of Russia \\ Lomonosov Moscow State University \\ GSP-1 Leninskie gory, Moscow, Russian Federation, 119991 \\ bituykova@yandex.ru \\ Pavel Kirillov \\ Department of economic and social geography of Russia \\ Lomonosov Moscow State University \\ GSP-1 Leninskie gory, Moscow, Russian Federation, 119991 \\ linard@mail.ru
}

\begin{abstract}
This article analyses the results of research on how Muscovites perceive the environmental situation. A mass poll of 800 residents of Moscow conducted in June-July, 2015 provided data for the analysis. Six municipal districts have been selected for polling: Novokosino, Perovo, Sokolinaya Gora, Mozhaisky, Krylatskoye, Novo-Peredelkino. The reasons were as follows: selection was to include districts with different levels of environmental pollution, districts located in semi-peripheral and peripheral parts of the city, approximately equally remote from the center.

The questionnaire consisted of the following parts: assessment of changes in the environmental situation in Moscow and in the district; ranking of polluters in the city and in the district; questions about environmental behavior of Muscovites.

The research was aimed at identifying the correlation between subjective perception of residents and objective spatial and environmental differentiation in Moscow as well as assessing the potential of environmental crowdsourcing in Moscow.

The article reviews the following aspects of how Muscovites perceive the environmental situation: assessment of environmental situation in the city and in model districts and comparison of their opinion to the actual environmental conditions; identification of the differences between Muscovites' perception of city polluters and objective ranking of polluters; environmental maturity of public consciousness among metropolitans and potential readiness of various groups for participating in environment protection measures.

Respondents' assessments diverge from actual data due to lack of knowledge and environmental illiteracy, difficulties in interpreting ecological information for an ordinary person, impossibility to assess potential threat of polluters, especially if a polluter is invisible and cannot be localized. The absence of accurate and objective criteria of environmental conditions is another reason for this divergence.

Residents of environmentally safe districts are prone to more positive assessments for the city in general. On the contrary, residents of less safe districts, tend to project problems of their district on the whole city, for example in Novokosino where waste incineration plant is located.

Muscovites' assessments largely depend on connectivity with the rest of the city, presence of unique natural sites (parks), proximity to polluters.

Keywords: environmental sociology, environmental situation in Moscow, state of environment, public opinion, spatial differentiation, modernization of public environmental consciousness.
\end{abstract}

(C) Maria Savoskul, Viktoria Bityukova Pavel Kirillov

\section{Introduction}

On the one hand, the opinion of residents of a large city may indicate actual environmental problems in the city. On the other hand, it reflects their readiness for vigorous and conscious ac- 
tions on environment protection and environmental maturity of public consciousness. The research highlighted the extent to which assessments of residents from various districts were consistent with actual spatial differentiation of environmental situation in the city; factors determining intracity differences in Muscovites' perception of the state of environment; possible catalysts for environmental consciousness and environmentally responsible behavior.

Though there was no actual increase in pollution level in Moscow during the 2000-s, environmental pollution remains a complex and paramount issue for Moscow and any large city. Finding a solution is at stake for residents, authorities and businessmen. Currently active involvement of residents in maintaining favorable environmental conditions is as important as the involvement of experts.

\section{Problem statement}

The research of summer 2015 was aimed at identifying the correlation between subjective perception of residents and objective spatial and environmental differentiation in Moscow as well as assessing the potential of environmental crowdsourcing in Moscow.

Environmental crowdsourcing uses information technologies to engage large numbers of people in diagnosing quality of the environment, public control and monitoring of polluters, drawing public attention toward environmental problems and forming environmental consciousness.

Tut-gryazi.net, a Transregional Environmental NGO, [1, 2] is an example of environmental crowdsourcing in Russia. During the project Internet users provided data on free waste utilization, mapped unauthorized dumping sites, etc.

NGO-s are not the only ones to initiate environmental crowdsourcing; Moscow authorities actively use this tool to solve multiple tasks. Moscow used it to discuss environmental strategy in July, 2015 [3].

Discussion involved more than 4.5 thousand residents; they put forward more than 5.5 thousand proposals regarding atmospheric air, water protection, noise and negative effect, vegetation, waste, environmental education.

\section{Field study: data and methods}

A mass poll of 800 residents of Moscow conducted in June-July, 2015 provided data for the analysis. Six municipal districts of Moscow have been selected for polling: Novokosino, Perovo, Sokolinaya Gora, Mozhaisky, Krylatskoye, Novo-Peredelkino. The reasons were as follows: selection was to include districts with different levels of environmental pollution, districts located in semi-peripheral and peripheral parts of the city, approximately equally remote from the center.

Within districts respondents were selected based on quota sampling consistent with sex-age structure of each district. Therefore, resulting sample structure is similar to sex-age structure (SES) of district population (Table 1).

The questionnaire consisted of the following parts: assessment of changes in the environmental situation in Moscow and in the district; ranking of polluters in the city and in the district; questions about environmental behavior of Muscovites.

Table 1

Poll districts

\begin{tabular}{cccc}
\hline District & $\begin{array}{c}\text { Population size based on } \\
\mathbf{2 0 1 0} \text { census, thousand people }\end{array}$ & $\begin{array}{c}\text { Number of respondents, } \\
\text { people }\end{array}$ & District share, \% \\
\hline Novokosino & 103.8 & 103 & 12.8 \\
Perovo & 139.4 & 168 & 21 \\
Sokolinaya Gora & 85.9 & 126 & 15.8 \\
Mozhaisky & 132.4 & 133 & 16.7 \\
Krylatskoye & 78.5 & 109 & 13.5 \\
Novo-Peredelkino & 111 & 161 & 20.2 \\
Total & 651 & 800 & 100
\end{tabular}




\section{Overview of studies on public environmental consciousness}

Publications pursue one of three directions. Research based on anthropological approaches and aimed at studying attitudes toward the environment, in particular, waste and garbage, in different communities. This direction includes monograph by M. Douglas, first published in 1966 and classics already. It studies various pollution concepts and taboos in different communities [4]. "Rubbish Theory: The Creation and Destruction of Value" by M. Thompson, focused on conceptual studying of garbage, was one of the earliest works in this group [5]. The majority of publications are dedicated to specific environmental and garbage issues in cities [6], attitudes toward pollution in public discussions [7].

The second direction represents systemic approach in studying correlation between society and environment, functioning of ecosystems and applied dimensions of solutions for sustainable development of ecosystems [8-11].

The third direction may be referred to as critical sociology or radical approach in studying society and environment. J. Bennet's publication on philosophical issues in political ecology was among the first ones in this group [12].

O. N. Yanickij, A. S. Ahiezer, A. V. Baranov, L. B. Kogan are eminent Russian scholars who have laid foundations for a discipline that later became known as environmental sociology [13-18]. In the 1990-s Moscow saw researches on Muscovites' attitude toward environmental situation in the city and changes in pollution [19-21].

\section{Evaluation of research}

There are several logical parts in the article: Muscovites' assessment of environmental situation in the city and in model districts and comparison of their opinion to the actual environmental conditions; identification of the differences between Muscovites' perception of city polluters and objective ranking of polluters; environmental maturity of public consciousness among metropolitans and potential readiness of various groups for participating in environmental protection measures.

\section{1. Assessment of environmental situation in the city}

According to summer 2015 poll, more than a half of respondents are ecological pessimists, they think that environmental situation is unfavorable or nearly catastrophic, $29 \%$ are neutral, $7 \%$ consider environmental situation to be relatively favorable (Fig. 1). The maximum share of ecological pessimist's falls within Muscovites aged 30 to 50. Increased share of negative assessments is typical for Krylatskoye, Novo-Peredelkino (Western Administrative District), which are peripheral and socially and economically relatively favorable districts, and for Perovo (Eastern Administrative District), that has maximum industrial area among analyzed districts.

According to the poll, residents in Eastern and Western Administrative Districts have different views on environmental situation in the city. That is consistent with objective differentiation of environmental situation. Traditionally industrially developed Eastern district that used to host major enterprises still bears main industrial burden. The majority of problem sites are located here. Largest CHPs (combined heat and power plants) near MKAD (Moscow Ring Road) form another powerful ring of stationary sources.

Respondents view Moscow from the perspective of their district. Those living in peripheral districts with no production enterprises and in districts with parks (Krylatskoye, Novo-Peredelkino, Perovo) consider the situation in their districts to be better than generally in Moscow.

High percentage of respondents from Krylatskoye who consider environmental situation in Moscow to be unfavorable ( $71 \%$ ) is most likely caused by them viewing Moscow from the perspective of their district which, according to the majority $(81.7 \%)$, is more environmentally favorable than Moscow is.

Locally, the number of respondents being optimistic while comparing the city and the district tends to grow, and the number of those being critical about the situation in the district tends to decrease.

In case of significant public attention to a large polluter, the residents of the district are less optimistic about the environmental situation. That we can see in Novokosino in terms of waste incineration plant (Fig. 2). 


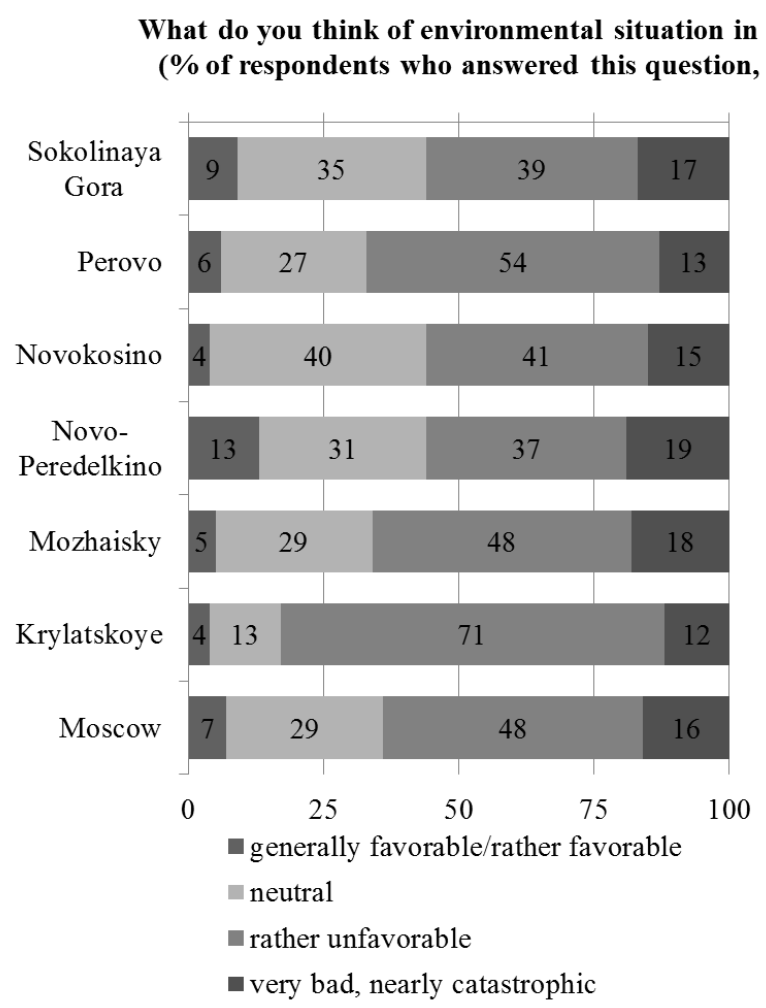

Fig. 1. Respondents' assessment of environmental situation in Moscow

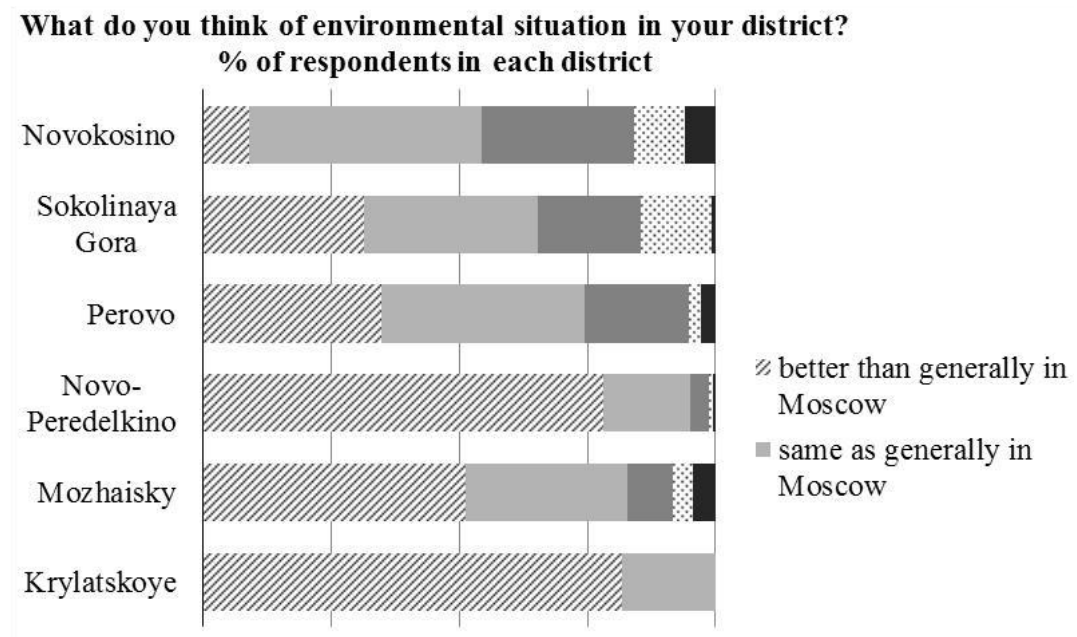

Fig. 2. Respondents' assessment of environmental situation in their district

Citizens tend to either move the problem away or remove themselves from it. A large city may have more negative assessments as compared to local assessments since respondents find themselves in their own districts every day and see that there is nothing disastrous going on there and the overall situation is favorable. At the mundane level environmental concerns are often caused by dumps of household garbage, dirty ponds, view of a production enterprise. Dynamic municipal improvement in 2010-2015 makes Muscovites feel like the environmental situation is generally favorable.

\section{2. Polluters}

According to the respondents, top polluters both for districts and for Moscow are cars. The majority of respondents (from $48 \%$ in Perovo to $78 \%$ in Krylatskoye) referred to cars as the pri- 
mary polluter for their own districts (Fig. 3, 4). Cars are indeed leading emitters; their share in emissions is even larger than citizens see it.

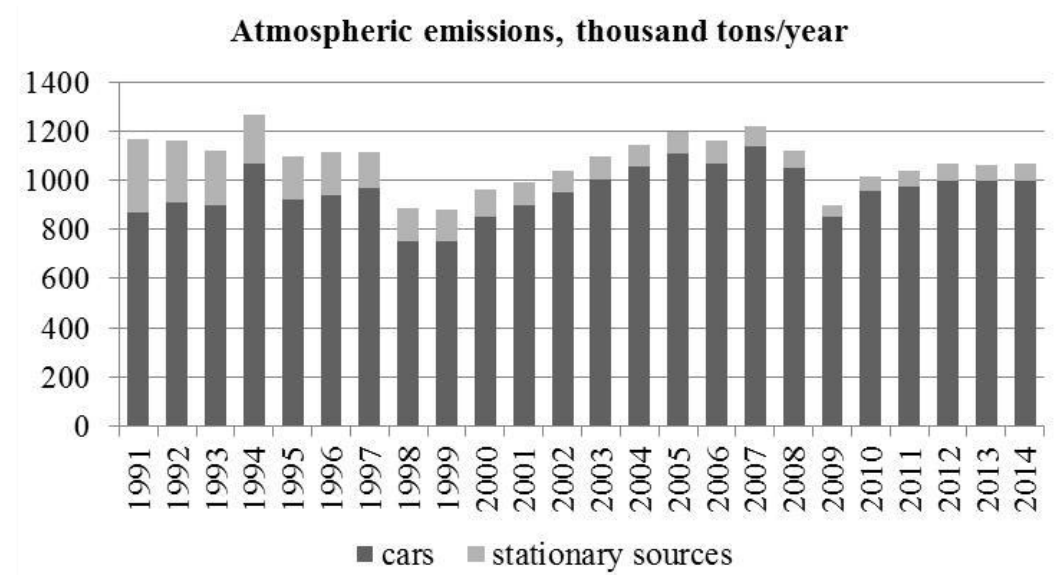

Fig. 3. Dynamics of atmospheric emissions from stationary sources and cars, 1991-2014, thousand tons/year

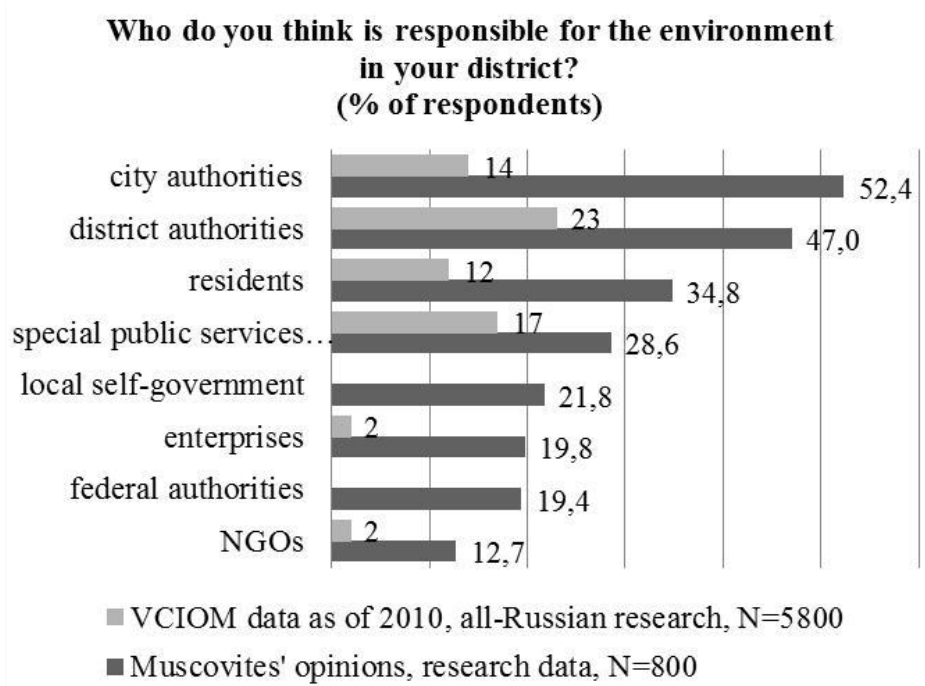

Fig. 4. Distributed responsibility for the environment (Question in VCIOM research: Who do you think should be responsible for environmental situation in your settlement?)

Past fifteen years have seen a more equally distributed car pollution that is moving from working to residential areas.

Car emissions have been calculated based on traffic intensity (STSI data), structure of traffic stream, haul, and traffic jam factor. Selected districts have car emissions proportional to the population size but for Mozhaisky district (Western Administrative District) where the share of emissions is larger due to Kutuzovsky Avenue that is daily used by up to 250 thousand cars. Perovo and Sokolinaya Gora (Eastern Administrative District) have the majority of car emission areas with the density of 1000-1300 tons $/ \mathrm{km}^{2}$, with certain areas near industrial zones of $3000-3500$, and certain areas of up to 4000 tons $/ \mathrm{km}^{2}$. Novokosino (Eastern Administrative District) is dominated by areas with the density of $1000-1300$ tons $/ \mathrm{km}^{2}$, but has no local highly dense areas. Krylatskoye and Mozhaisky have the majority of car emissions areas with the density of $1500-2000$ tons $/ \mathrm{km}^{2}$ along the streets. Novo-Peredelkino (Western Administrative District) has the same density along the roads, but has less internal pollution areas of 500-1000 tons $/ \mathrm{km}^{2}$.

Descending ranking of districts based on emissions looks as follows: Perovo, Sokolinaya Gora (number of areas), Krylatskoye, Mozhaisky, Novokosino, Novo-Peredelkino. Car pollution 
goes down from the centre to periphery. However, residents' assessments of pollution in their districts are slightly different (Table 2) since residents of Perovo and Sokolinaya Gora tend to exaggerate the role of industry in pollution.

Table 2

Main polluters for Moscow and for the districts; respondents were to choose up to three polluters $(1$ - Moscow, 2 - district); \% of the number of respondents in every district

\begin{tabular}{|c|c|c|c|c|c|c|c|c|c|c|c|c|}
\hline \multirow[t]{2}{*}{ Polluters } & \multicolumn{2}{|c|}{ Krylatskoye } & \multicolumn{2}{|c|}{ Mozhaisky } & \multicolumn{2}{|c|}{$\begin{array}{c}\text { Novo- } \\
\text { Peredelkino }\end{array}$} & \multicolumn{2}{|c|}{$\begin{array}{l}\text { Sokolinaya } \\
\text { Gora }\end{array}$} & \multicolumn{2}{|c|}{ Perovo } & \multicolumn{2}{|c|}{ Novokosino } \\
\hline & 1 & 2 & 1 & 2 & 1 & 2 & 1 & 2 & 1 & 2 & 1 & 2 \\
\hline cars & 72 & 78 & 84 & 56 & 90 & 66 & 75 & 48 & 75 & 49 & 68 & 61 \\
\hline $\begin{array}{l}\text { production } \\
\text { enterprises }\end{array}$ & 51 & 10 & 49 & 7 & 37 & 7 & 55 & 40 & 54 & 35 & 83 & 17 \\
\hline $\begin{array}{l}\text { household waste, } \\
\text { dumping sites }\end{array}$ & 61 & 17 & 47 & 10 & 54 & 7 & 25 & 0 & 59 & 13 & 72 & 74 \\
\hline $\begin{array}{l}\text { energy facilities } \\
\text { (Nuclear, Hydro, } \\
\text { Central Heating } \\
\text { Power Plants) }\end{array}$ & 27 & 14 & 24 & 11 & 15 & 0 & 13 & 6 & 16 & 8 & 17 & 9 \\
\hline construction & 0 & 6 & 0 & 10 & 0 & 14 & 0 & 5 & 0 & 2 & 0 & 6 \\
\hline felling & 0 & 14 & 0 & 4 & 0 & 4 & 0 & 0 & 0 & 1 & 0 & 1 \\
\hline residents themselves & 0 & 2 & 0 & 7 & 0 & 6 & 0 & 3 & 0 & 5 & 0 & 2 \\
\hline fires and emergencies & 11 & 0 & 3 & 0 & 5 & 0 & 13 & 0 & 6 & 0 & 14 & 0 \\
\hline $\begin{array}{c}\text { nuclear waste } \\
\text { transportation and } \\
\text { disposal }\end{array}$ & 10 & 0 & 7 & 0 & 10 & 0 & 0 & 0 & 14 & 0 & 9 & 0 \\
\hline domestic appliances & 6 & 0 & 4 & 0 & 4 & 0 & 2 & 0 & 5 & 0 & 0 & 0 \\
\hline
\end{tabular}

Respondents from all districts exaggerate the role of industry in pollution. About half of respondents consider industry to be the main polluter in the city. In Novokosino $82.5 \%$ of residents refer to industry as the main source; nearly $40 \%$ believe that waste incineration plant is the key local problem. Respondents in Perovo and Sokolinaya Gora (35\% and $40 \%$ respectively) have mentioned industry among polluters in their district. 53.5\% respondents in Perovo and 54.7 \% in Sokolinaya Gora think that industry is the main polluter in Moscow. Major industrial polluters in Moscow are oil refinery in Kapotnya and CHPs that are absent from the above mentioned districts but for a small CHP-11 on the border of Perovo and Sokolinaya Gora. In this case problems of a district are projected on the whole city (Table 3).

Household waste and dumping sites are a pressing problem for modern cities, yet it has not cemented in citizens' consciousness. Poll respondents have placed household waste and dumping sites on the third place both for districts and for Moscow.

Residents of Novokosino, where waste incineration plant is located, are most responsive to this problem $(74 \%$ of respondents in the district). The district regularly witnesses protests against this enterprise. Likewise, residents of Perovo (59.4\%) and Sokolinaya Gora (25\%) often mention household waste and dumping sites.

According to respondents, other polluters are less significant. Energy facilities occupy the fourth place. Partially this is due to many respondents referring to CHPs as to production enterprises. $23 \%$ of respondents mention energy facilities as polluters for Moscow and $8 \%$ for districts since these districts have no CHPs, only district boiler houses. 
Table 3

Main pollution indices for Moscow and certain municipal districts, 2014

\begin{tabular}{ccccc}
\hline District & $\begin{array}{c}\text { Annual solid household waste dispos- } \\
\text { al, thousand cubic meters }\end{array}$ & $\begin{array}{c}\text { Emissions, thousand tons/year } \\
\text { Stationary } \\
\text { sources }\end{array}$ & Cars & Total \\
\hline Moscow (former boundaries) & 20161.8 & 59.9 & 936 & 992.1 \\
Krylatskoye & 159.3 & 0.02 & 6.0 & 6.0 \\
Mozhaisky & 150.2 & 0.19 & 15.5 & 15.7 \\
Novokosino & 109.53 & 0.01 & 6.7 & 6.8 \\
Novo-Peredelkino & 117.4 & 0.04 & 2.1 & 2.2 \\
Perovo & 158.6 & 0.8 & 7.6 & 8.4 \\
Sokolinaya Gora & 94.65 & 0.59 & 6.7 & 7.3
\end{tabular}

The only polluter as often mentioned for the district as for Moscow in Western Administrative District are cars. There are few people, less than $15 \%$ for each district, who note polluters typical for their district only.

In Western Administrative District residents of Novo-Peredelkino are most optimistic about polluters which is rather logical as this district is outside MKAD and many residents consider it to be ecologically favorable. Key polluters in the district for residents are cars and construction. Residents of Krylatskoye also note household waste, energy facilities, and felling, residents of Mozhaisky mention household waste, energy facilities, and construction (Table 2).

The role of city polluters that can be influenced by large-scale investment aimed at technological modernization in production is currently declining. Citizens see cars as predominant polluters which is true. However, most Muscovites are not ready to stop driving cars. Ease of travel compensates for the harm, especially for residents of peripheral and socially and economically favorable districts.

Such tolerance toward cars clearly illustrates latent nature of environmental factors in residents' consciousness, as the result they tend to underestimate environmental threats and consequences of current actions. Social studies call this phenomenon the shift of future plans in human preferences. Sometimes, human behavior is irrational, primary day-to-day concerns demand tools that will have unfavorable consequences.

Attitude toward dumping and disposal of household waste, garbage in the streets demonstrates latency of environmental factor in Muscovites' consciousness. Polluting role of household waste is growing; however, Muscovites do not consider it to be a real environmental threat. The idea of dirty plants and factories has deep roots in residents' consciousness. Opinion polls refer to cars as polluters, but see no danger in garbage. This problem cannot be solved without residents; while Muscovites do not understand it they are not ready to help solving it. Lack of mass media coverage and environmental education, including at schools, may be among possible reasons.

A lot of respondents in Eastern Administrative District mention polluters in their districts.

There are no production enterprises in Western Administrative District, but traffic load is no less intense, however, residents tend to underestimate the threat of air pollution in their district. This means that residents of peripheral districts with large parks do not understand the danger of cars as the primary air polluter.

\section{3. Modernization of public environmental consciousness}

Moscow undergoes a more rapid social modernization than other Russian regions, including greater environmental responsibility of residents. Comparative analysis of the poll data and VCIOM (Russian Public Opinion Research Centre) polls data of the 2000-s [22] shows that Muscovites thrice as often as Russians believe that they are responsible for the environment $(34.8 \%$ and $12 \%$ respectively) (Fig. 4). Those respondents may become proactive citizens concerned with the environmental situation. 
However, environmental modernization has not completed in Moscow since only $12.7 \%$ rest responsibility for the environment on environmental NGOs and relatively small amount of respondents $(19.4 \%)$ believe that production enterprises are environmentally responsible, the indices across Russia are even lower (Fig. 5).

Key features of modernization of environmental consciousness and readiness for environmentally responsible behavior are: vigorous interest in solving environmental problems, involvement in environment protection measures, awareness of the environmental situation and main polluters and pollution indicators, personal responsibility for the environment.

$57 \%$ of Muscovites are prepared to take part in environment protection measures, about one-fifth are uncertain and about one-fourth are not ready for vigorous actions, which correlates with the number of those who consider environmental situation in the city to be unfavorable or rather unfavorable.

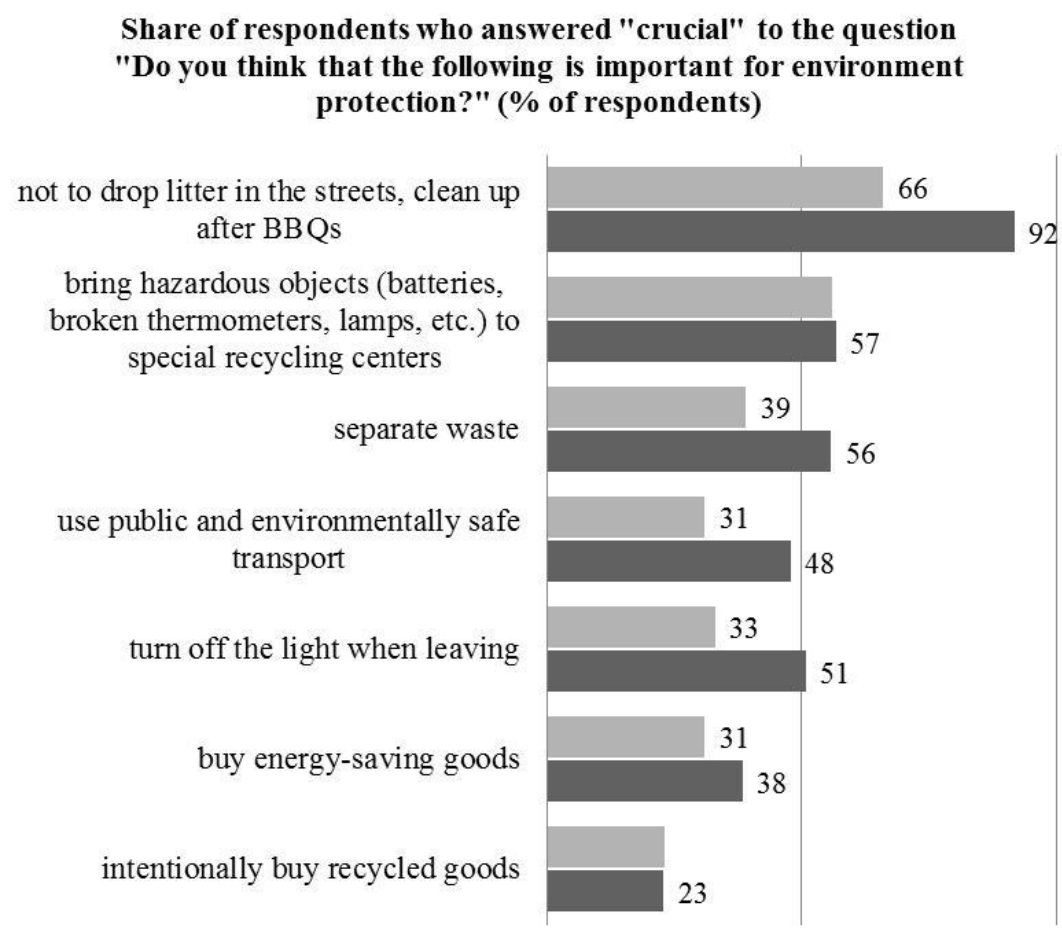

" VCIOM data as of 2010, all-Russian research, $\mathrm{N}=5800$

Muscovites' opinions, research data, $\mathrm{N}=800$

Fig. 5. Readiness for environmentally responsible behavior among Muscovites and Russians

The maximum share of respondents ready for environment protection measures live in Mozhaisky and Novo-Peredelkino. Large number of potential environmental activists in these districts reflects rapid changes in usual urban environment due to dynamic urban development. Moreover, their residents that have recently moved in have chosen based on favorable environmental conditions and, therefore, are ready to protest in case of negative changes.

In Moscow differentiation based on potential readiness for involvement in various environment protection measures is more obvious in age groups, than in spatial groups. Environmental modernization is more typical for younger people, thus they are ready for actions. Young people are traditionally more socially active for a number of social and economic reasons, while residents aged 45-55; at the height of professional growth often have minimum incentives for public actions.

Answers on importance of different types of environmentally responsible behavior demonstrate that, as compared to other Russian regions, Muscovites understand its key role (Fig. 5). Rankings of important actions are similar for Muscovites and Russians as well as the share of those 
who believe that those environmental actions make no difference. But the numbers of those who think that these actions are crucial or rather important vary.

Volunteer clean-ups are most popular among Muscovites ready for environment protection measures (62.2\% of respondents ready to participate in vigorous actions). That means that common Muscovites associate environmental problems and nice view (absence of garbage in the streets).

As for more systemic and regular actions on stabilizing environmental situation, such as public hearings, environmental education, rallies and protests, the number of respondents ready to take part decreases (Fig. 6), but, compared to all-Russian data [22], the share of proactive Muscovites is larger.

The same is true for Muscovites being ready to stop driving cars in order to protect the environment $-20 \%$ are not ready to use public and environmentally safe transports and $5.2 \%$ are uncertain.

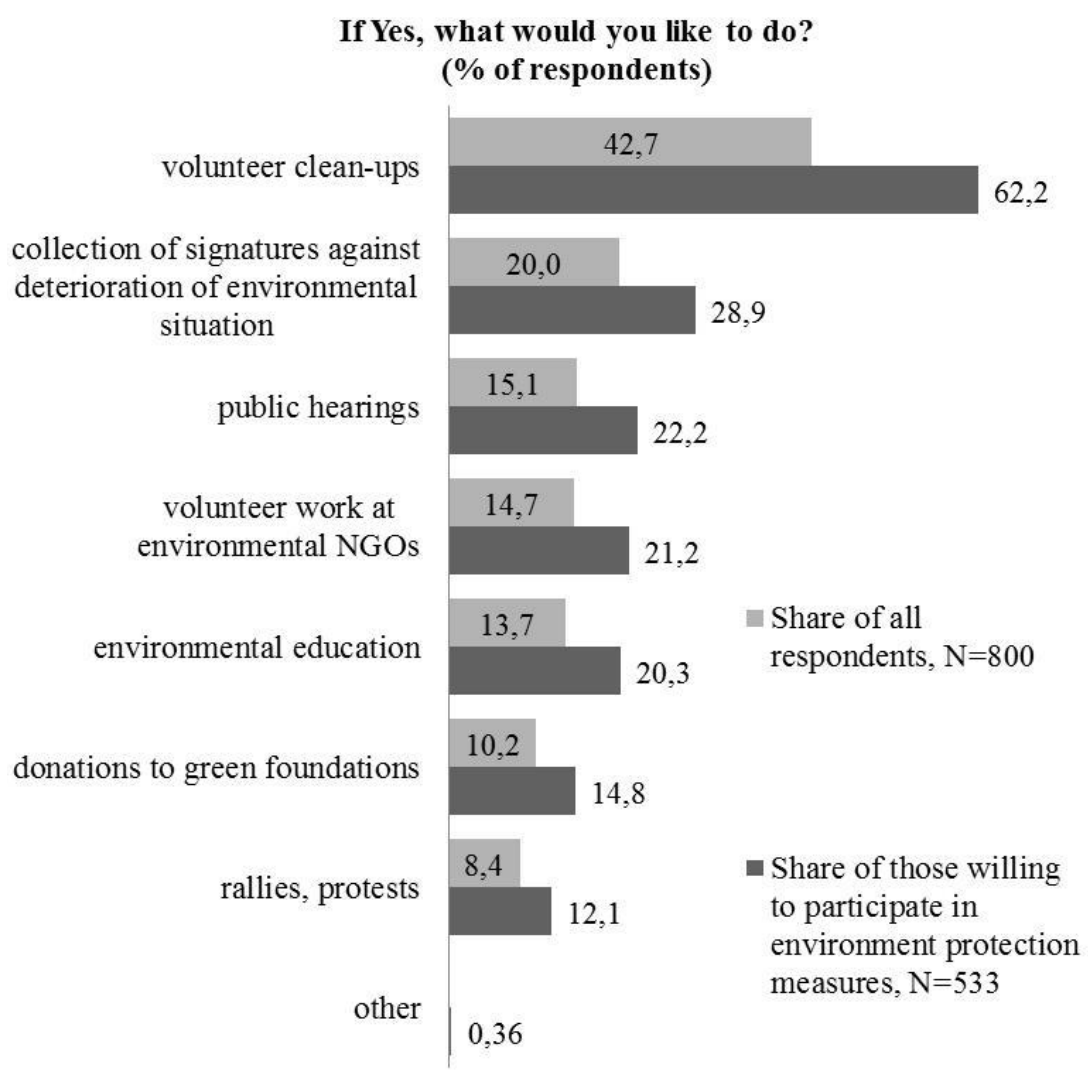

Fig. 6. Muscovites readiness for environmentally responsible behavior

The vast majority of Muscovites understand key role of environmentally responsible behavior and involvement in environment protection measures. But most of them are ready for passive environmentally responsible behavior, related to family budget economy (energy saving, use of public transport, energy-saving goods). Few respondents choose actions requiring regular efforts.

\section{Conclusion}

Population assessments generally reflect actual environmental situation and spatial differentiation of favorable environmental conditions in Moscow. Subjective assessments of environment in different districts influence perception of quality urban environment and housing market in the city. Moscow has no significant differences between districts regarding assessments of environmental problems; those differences are more obvious for larger administrative districts.

Since the collapse of the USSR, Muscovites have become more concerned about the environment. That is the result of better social conditions and higher living standards in Moscow for the reviewed period, as well as mass media attention toward environmental problems. 
Some residents underrate environmental problems in their district (e. g. residents of Krylatskoye underestimate the threat of cars pollution in their district), others are too pessimistic (e. g. residents of Novokosino in case of waste incineration plant).

Respondents' assessments diverge from actual data due to lack of knowledge and environmental illiteracy, difficulties in interpreting ecological information for an ordinary person, impossibility to assess potential threat of polluters, especially if a polluter is invisible and cannot be localized. The absence of accurate and objective criteria of environmental conditions is another reason for this divergence.

Residents of environmentally safe districts are prone to more positive assessments for the city in general. On the contrary, residents of less safe districts, tend to project problems of their district on the whole city, for example in Novokosino where waste incineration plant is located.

Muscovites' assessments largely depend on connectivity with the rest of the city, presence of unique natural sites (parks), proximity to polluters.

Subjective assessment of environmental situation in a large city often turns out to be more important than actual statistical assessment in terms of city administration and self-administration. Public opinion, environmental maturity of public consciousness, prefer ability of active or passive environment protection measures may create an information field and intensify nature conservation activities in districts or in the city. The majority of environment protection measures are not initiated by residents but are organized formally. Until now, despite a more dynamic interaction between population and authorities in management, cultural and even urban development spheres, potential of environmental consciousness as an important resource for territorial development and better urban environment remains unclaimed and is not used by municipal administration or environmental NGO-s.

\section{Acknowledgements}

The research was conducted with support from Russian Geographical Society: Integral environmental evaluation of Russian cities and regions grant - public response 07/2014-П1.

\section{References}

[1] Karta Kraudsorsinga v Rossii. CROWDSOURCING.RU. Available: http://crowdsourcing.ru/crowdmap

[2] Ecokarta.ru. Available: http://www.ecokarta.ru

[3] Kraudsorsing. Available: http://crowd.mos.ru/archive/

[4] Douglas, M. (2001). Purity and Danger: an analysis of the concept of pollution and taboo. London, New York, 272. doi:10.4324/9781315015811

[5] Thompson, M. (1979). Rubbish Theory: The Creation and Destruction of Value. New York: Oxford University Press, 240.

[6] Melosi, M. V. (2005). Garbage in the Cities: Refuse reform and the Environment. Pittsburgh: University of Pittsburgh Press, 320.

[7] Bickerstaff, K., Walker, G. (2003). The place(s) of matter: matter out place - public understanding of air pollution. Progress in Human Geography, 27 (1), 45-67. doi: 10.1191/ 0309132503ph412oa

[8] Bityukova, V., Sokolova, E. (2008). On the brink of collapse Moscow's tangled traffic. Osteuropa: Zeitschrift fuer Gegenwartsfragen des Ostens, 58 (4-5), 351-358+493.

[9] McGinnes, M. D., Ostrom, E. (2014). Social-ecological system framework: initial changes continuing challenges. Ecology and Society, 19 (2), 30. doi:10.5751/es-06387-190230

[10] Ostrom, E. (2009). General framework for analyzing sustainability of social-ecological systems. Science, 325 (5939), 419-422. doi:10.1126/science.1172133

[11] Plieninger, T., Van der Horst, D., Schleyer, Ch., Bieling, C. (2014). Sustaining Ecosystem services in cultural landscape. Ecology and Society, 19 (2), 59. doi:10.5751/es-06159-190259

[12] Bennet, J. (2010). Vibrant Matter: a political ecology of things. London, Durham: Duke University Press, 200. doi:10.1215/9780822391623

[13] Ahiezer, A. S., Kogan, L. B., Yanickij, O. N. (1969). Urbanizaciya, obshhestvo i nauchno-tehnicheskaya revolyuciya. Voprosy filosofii, 2, 43-53. 
[14] Baranov, A. V. (1984). Vospriyatie zagryazneniya gorodskoy sredy naseleniem goroda. Byulleten' Komissii SSSR po delam UNESKO, 3-4.

[15] Kogan, L. B. (1967). Urbanizaciya - obshhenie - mikrorayon. Arhitektura SSSR, 4, 39-42.

[16] Kogan, L. B., Listengurt, F. M. (1975). Urbanizaciya i priroda. Priroda, 3, 12-25.

[17] Medvedev, I. V., Aladsheva, A. A. (2001). Ekologicheskoe soznanie. Moskva, 384.

[18] Yanickiy, O. N. (1998). Ekologicheskaya sociologiya. Sociologiya v Rossii, Moskva: Izdatel'stvo Instituta sociologii RAN, 496-517.

[19] Slobodskoy, D. I. (2003). Izmenenie territorial'noy struktury promyshlennogo zagryazneniya Moskvy v 90-e gody. Vestnik Mosk. un-ta, ser. 5, geogr, 2, 50-59.

[20] Fomichev, Y. K. (1999). Moskvichi ob ekologicheskih i transportnyh problemah stolicy. Simptom. KTKISMI, Izd. Pravitel'stva Moskvy, 8 (111), 11-22.

[21] Yakovlev, S. D. (1999). Social'noe samochuvstvie i cennostnye orientacii moskvichey. Gorod, pravitel'stvo, lyudi. KTKISMI, Izd. Pravitel'stva Moskvy, 8 (111), 11-22.

[22] Abramov, K. V. Rossiyane o sostoyanii okruzhayushhey sredy po rezul'tatam sociologicheskih issledovaniy. Available: www.wciom.ru 